\title{
Climate impact on surface and groundwater in North Africa: a global synthesis of findings and recommendations
}

\author{
Younes Hamed ${ }^{1,6} \cdot$ Rihab Hadji2 $^{2,6} \cdot$ Belgacem Redhaounia $^{3,6} \cdot$ Karim Zighmi $^{2,6} \cdot$ Fathi Bâali ${ }^{4,6} \cdot$ Attiya El Gayar ${ }^{5,6}$
}

Received: 22 June 2017 / Accepted: 13 April 2018 / Published online: 11 July 2018

(c) The Author(s) 2018

\begin{abstract}
Climate change is having short- and long-term impacts on surface and groundwater in the northern part of the African continent. This has led to a wide range of consequences that have added pressure on the groundwater systems in this part of the world. Among such pressures, we can cite the mal-distribution and the irregularity of precipitation and ice, flooding, evaporitic sediments input by the drainage net, water degradation, mud stagnation in dams, dead tranche, drought, decreasing of the natural recharge and increasing of the groundwater abstraction, conflict between trans-boundary waters, desertification, imbalance between the regions, migration, revolution, socio-economic imbalance, etc. Actually, watermonitoring networks indicate noticeable hydrogeologic variations and a rise of the groundwater salinity. It was confirmed by the geochemical analysis of water resources that showed scattered data between the northern part characterized by low mineralized groundwater (TDS ranging 0.4-3 g/l) and the southern area where the salinity ranges from 2.5 to $90 \mathrm{~g} / \mathrm{l}$. The obtained values are far above the permissible limits for both human consumption, agricultural and tourist activities. These effects, when compounded, are anticipated to worsen the situation and to constitute veritable threats for social and economic development in these regions of North Africa (Morocco, Algeria, Tunisia, Libya, Egypt, etc.). The potential solutions consist of taking urgent to utilize the intelligent technology (bio and nano-technology), policies relevant policies to manage water resources, and the engagement of private, civil, and international sectors if a major crisis is to be averted (collective effort).
\end{abstract}

Keywords Climate change $\cdot$ Water resources $\cdot$ Water quality $\cdot$ North Africa

\section{Introduction}

In North African arid/desert lands, groundwater (depth $>500 \mathrm{~m}$ ) is the only source of water supply for most of the local demand (agricultural, industry, tourism, and domestic). Just like most of the countries in the world, the populations in southern Mediterranean countries live under water stress $(<4501 /$ person/year), defined as those using more than $20 \%$ of their renewable water resources (WBGU 2003), while the withdrawal of over $40-50 \%$ mean serious water stress (Pittock 2007; Melki et al. 2017; Hamed et al. 2017a, b; El Gayar and Hamed 2017; Hamed 2017). Currently the ONU estimates that in 2025, 25 African countries are expected to suffer from water scarcity or water

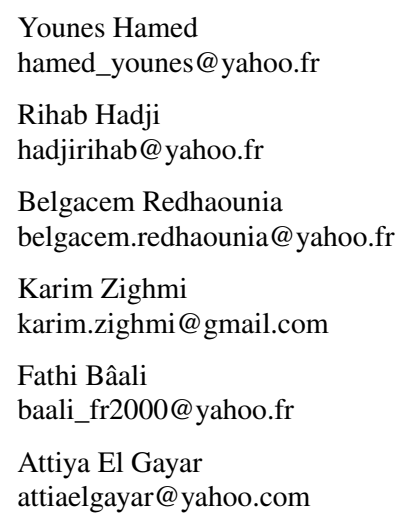

Department of Earth Sciences, Sciences Faculty of Gafsa, Research Unit of 3G-Gabes-Tunisia, Gafsa, Tunisia

2 Department of Earth Sciences, Institute of Architecture and Earth Sciences, Sétif University, Sétif, Algeria

3 Water Researches and Technologies Center Borj-Cedria (CERTE), BP 273, 8020 Soliman, Tunisia

4 Department of Earth Sciences, Sciences Faculty of Tebessa, Tebessa University, Tebessa, Algeria

5 Agriculture Research Centre, Soils, Water \& Environment Research Institute, MINAGRI, Giza 12619, Egypt

6 Department of Earth Sciences, Faculty of Sciences of Gafsa, International Association of Water Resources, Southern Mediterranean Basin, Gafsa, Tunisia 
stress. Also, according to UNEP (2006, 2010, 2011), about 1100 million people do not have access to clean drinking water (surface and/or groundwater), and contaminated water is the direct cause of 5 million deaths every year, most of them occurring in sub-desertic Africa. Recently, in the 1st international symposium (WREIANA 2017) of "Water Resources and Environmental Impact Assessment in North Africa"-March 24-26, 2017 Gafsa, Tunisia, noted that water stress will increase significantly in the region of North Africa worsening the current situation and exacerbating the general drying trend for these regions (Melki et al. 2017; Hadji 2017; Ayadi et al. 2017a, b; Besser et al. 2017a; El Gayar and Hamed 2017; Hamed et al. 2017a, b; Kachi et al. 2017). In this perspective, given the potential for climate change in conjunction with these parameters, there is a need to examine the potential for the increased water scarcity in North Africa lands.

Both anthropogenic and natural activities affect the "Blue Gold" cycle, often with additive effects. Aerosols and gas emission, irregularity of the rain cycle, change in precipitation (form liquid rain to coarse hail), deforestation, urbanization, additive for agricultural activities (pesticides, fungicides, fertilizers), diseases (cancer, cardiovascular, respirator, diabetic, hepatic, etc.), industrialization, industrial and domestic wastewater, increase of the evapo-transpiration, soil degradation (texture and structure), landslides, etc., have significant impacts on the water cycle and on human life.

This scientific paper has already described the importance of surface and ground water in North Africa, noting that throughout the continent people value water as much as they value life. It has also explained the forms of water availability in North Africa and the climate impact on the water resources in this arid region. The natural and the anthropogenic consequences of climate change are rated to have significant direct and indirect effects and while the countries of North Africa have contributed little to the magnitude of the global problem, they stand to bear some of the serious consequences. This work also explores what methods can be used to express the impact of the combined effects of population growth, environmental change, and climate change. Finally, this work makes recommendations to adapt to this climate change in North Africa.

\section{Description of the study area}

The study area is located in the southern Mediterranean basin, bordered to the south by the great desert of Africa (Fig. 1). Climate effect place in North Africa over multimillennial timescales has led to the region experiencing multiple episodes of conditions wetter than nowadays, interspersed with dry phases. The water resources available in this region today are limited under Saharan conditions, but a legacy of groundwater resources remaining from wetter conditions during the late quaternary (Pleistocene/Holocene), are a significant asset. The major regional multi-aquifer systems are at depths between (500 and $3000 \mathrm{~m}$ ) (Hamed et al. 2008, 2010a, b, 2014; Mokadem et al. 2016; Hamed 2017).

The climate of the study area is typical Mediterranean with some Atlantic oscillations, with dry to desertic summers and rainy autumns and springs. Precipitations (solid/ liquid/gas) are strongly related to the altitude, seasonal changes, with about $90 \%$ occurring in the period from September to April (recharge period). The Atlas range of North Africa constitutes the recharge area of the totality of the northern part of the study area, but the Sahara constitutes the discharge area of the southern part of this study area. This part (Grand Erg of North Africa) is more arid $\left(45{ }^{\circ} \mathrm{C}<\right.$ Temp $\left._{\text {summer }}<60{ }^{\circ} \mathrm{C}\right)$ receiving an annual average close to $50 \mathrm{~mm} / \mathrm{year}$. It is characterized by violent sandstorms.

\section{Climate change effects on surface water in North Africa}

The most noticeable impacts of climate change, which have been widely studied and discussed by a great number of scientific papers, are mainly related to surface water quality and quantity changes. The climate changes' direct effects are expected to affect soil, land cover, and hydrologic systems by increasing temperature, high evapo-transpiration potential and great variability of rainfall in terms of timing, form and quantity expressed by increasing frequency of extreme events as floods and droughts (IPCC, TAR 2001; Bates et al. 2008; Hammouri et al. 2016; Hamed 2018). The less replenishment of surface water will be more obvious in semi-arid and arid regions where most of the predictable impacts are already occurring regardless of climate variability, and climate change is expected only to exacerbate these trends (Hamed 2017; Hammouri et al. 2016).

North-African countries are facing numerous environmental challenges related mainly to water scarcity issues, as the major economic sectors, especially agriculture, are extremely vulnerable to current climate sensitivity (Radhouane 2013; Hamed 2017, 2018). The study area has undergone arid to semi-arid climate changes marked by seasonal contrasting climatic variables. Influenced by a temperate Mediterranean climate, with moderately hot summers $\left(30{ }^{\circ} \mathrm{C}<\mathrm{Temp}<50{ }^{\circ} \mathrm{C}\right)$ and cold winters $\left(-15{ }^{\circ} \mathrm{C}<\mathrm{Temp}<20{ }^{\circ} \mathrm{C}\right)$, rainfall gradually decreases from the Atlas range (north) to the Sahara "Grand Erg of North Africa" platform (south) (Mokadem et al. 2016; El Gayar and Hamed 2017). In many days, North Africa suffers from sandstorm effects from the Grand Erg (North Africa 


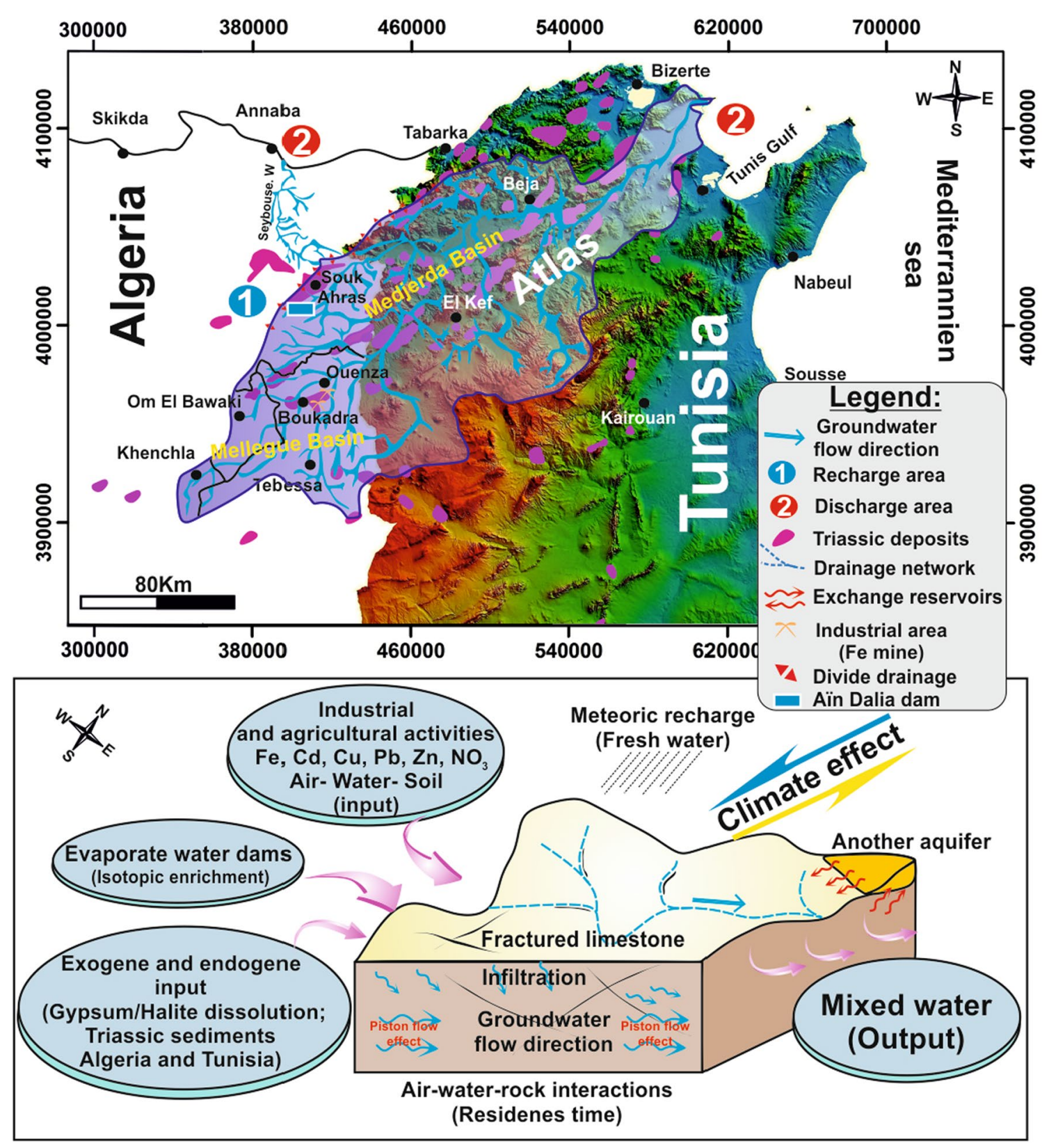

Fig. 1 Location of the study area and the origins of groundwater mineralization in the transboundary Algero, Tunisian of Majerda Basin (Hamed 2015a, b)

Sahara). On March 2018, the Mediterranean basin (southern Europe and northern Africa) experienced a major climate change. Sea waves of the order between 5 and $10 \mathrm{~m}$ in height have been observed in the coastal regions (Algeria, Tunisia, Spain, and Portugal), snowstorms in the Atlasic regions of North Africa (higher than $1000 \mathrm{~m}$ in altitude) and wind storms $(150 \mathrm{~km} / \mathrm{h})$ in the desert regions of the Erg Basin of northern Africa (Algeria, Tunisia, and Libya). These sandstorms from the south are the primary causes of desertification (advancing of sand dunes) from south to north, especially in the Grand Erg Sahara (Oriental and Occidental).
The southern Mediterranean region faces an increasing water demand for agriculture, industry, and tourism, while climate change projections forecast an increase of temperature, decrease of precipitation, and increased occurrence of extreme events.

The outline of the Mediterranean basin, and especially North Africa, is very vulnerable to flooding. The flood is the most prevalent disaster in these regions. The typical example is the Majerda Basin (transboundary basin between Algeria and Tunisia). Figure 1 shows the origins of surface water mineralization in the transboundary Algero, Tunisian 
Majerda Basin (Hamed et al. 2012). The high altitude of Atlas range of NE Algeria (recharge area), constituted by the Triassic friable deposits (gypsum, halite, clay, etc.), the mines of "Fer" discharges (Hajjar, Boukhadra, Ounza, etc.) and currently this basin will also suffer from the discharge of the mining activity of phosphate "phosphoric acid" from Ferphos (Tebessa/Souk Ahras: under study project), the intensive agricultural activities caused many problems in the drainage network of the Majerda Basin (Figs. 1, 2). The most detrimental damage is observed in the discharge area (Gulf of Tunis, Tunisian territory). Figure 3a shows the climate effect on surface water in the Tabarka region and especially in the Sidi El Barrak Dam. This dam is targeted to store a large stock of water for use in agricultural, industrial, domestic, and tourist activities, but as a result of this climate change, the water quantities in the dam have dwindled down and are of bad quality; on the other hand, the amounts of sediments have become very important (Fig. 3b). The same phenomenon is observed in the Algerian territory (Aïn Dalia, Kissir, Ourkis, Koudiet Lamdaouar, etc.), especially in the Béni Haroun Dam, which is one of the biggest dams in North Africa.

The Beni Haroun Dam (Fig. 4) is a large strategic hydraulic complex in Algeria located in the Mila area in northeastern Algeria. This dam is classified as the second dam in North Africa after that of "as-Sad al-Aly"Assouan, Egypt, with 169 billion cubic meters of water. The 120-m-high dam is the largest dam in Algeria with a capacity of 960 million cubic meters. The dam consists of a dike reinforced with 1.5 million cubic meters of compacted rolled concrete. With its large raw water pumping station, which has a capacity of $180 \mathrm{MW}$, the dam supplies drinking water by direct transfer "canalization of meteoric water" to several areas bordering the Mila region, including Jijel, Constantine, Oum El Baouaki, Batna, and Khenchela Basins. The dam also provides a significant amount of irrigation water for a few hundred hectares of farms in neighboring areas. This dam is currently suffering from siltation and water capacity reduction problems due mainly to climatic fluctuations in northern Africa (Fig. 4).

Riverine floods are a natural phenomenon; they have always occurred, and populations have benefited from them to whatever extent possible (for example, in ancient Egypt the natural annual flooding of the Nile brought much-needed nutrients to irrigated soils) (El Gayar and Hamed 2017). In recent times, humans have become more exposed to flood risk as encroachment into flood plains and lack of flood response plans increased the damage potential. The typical example is Bousalem region at the NW Tunisian when the impact of the floods is very important.

In the southern part of Tunisia, another phenomenon unfolds. The stagnation of surface water at the Dams (El Khangua, El Oudei, Lalla, Om Lagsab, and Tataouine) and at the collinear lakes, and due to the high evaporation $\left(40<\mathrm{Temp}_{\text {summer }}<55^{\circ} \mathrm{C} / 12\right.$ to $14 \mathrm{~h} /$ day $)$, and about the stable isotope composition $\left(1.64 \%\right.$ o for $\delta^{18} \mathrm{O}$ and $0.56 \%$ o for $\delta^{2} \mathrm{H}$ ), the waters become too salty, degrading the waters of the shallow aquifers (the good quality aquifer " $2<$ TDS $<3 \mathrm{~g} / \mathrm{l}$ " is recharged by poor-quality water " $4<$ TDS $<6 \mathrm{~g} / \mathrm{l}$ "). Several other problems appear following this phenomenon of climate change such as: eutrophication " $\mathrm{H}_{2} \mathrm{~S}$ production via the bacteria", water diseases,
Fig. 2 Causes of groundwater degradation in Tunisia (Hamed 2015a, b)

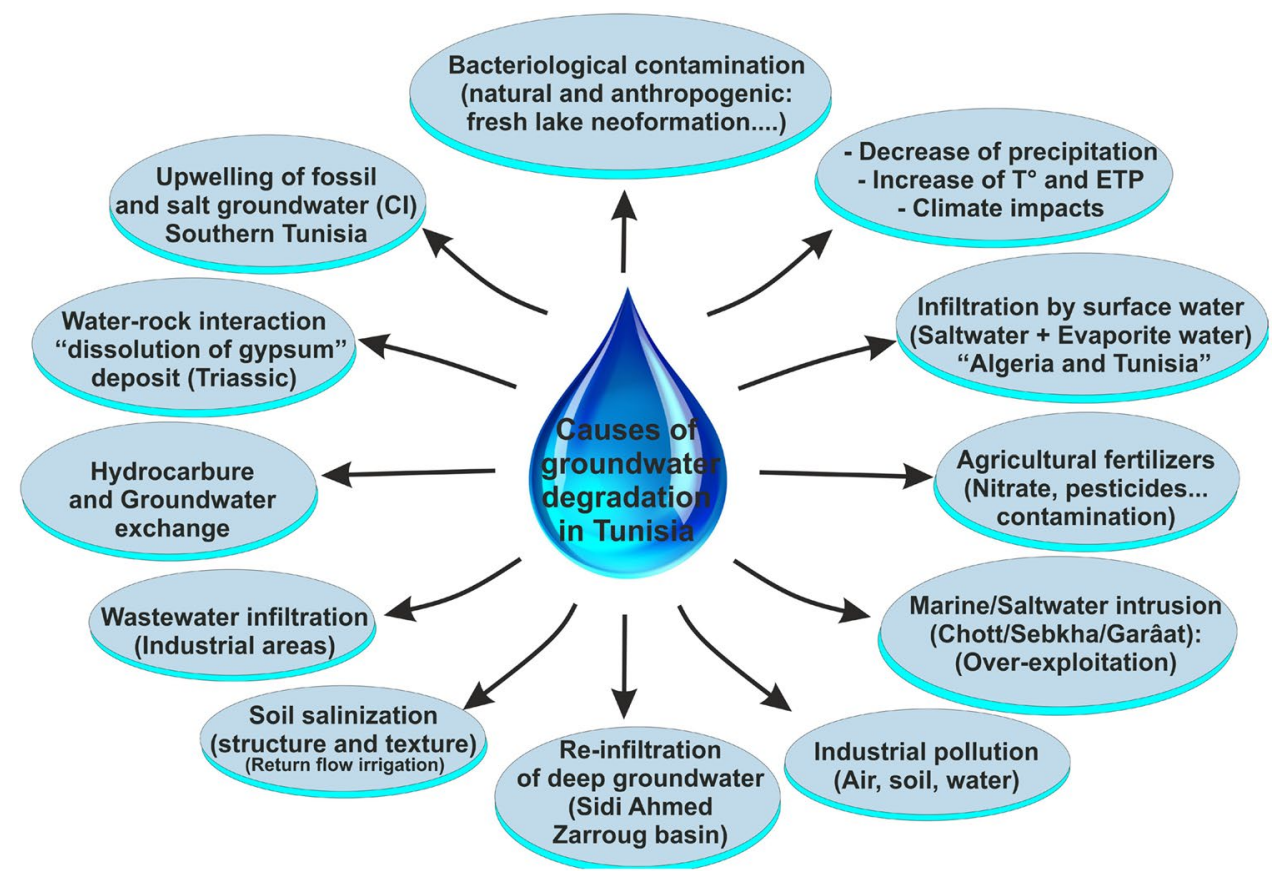



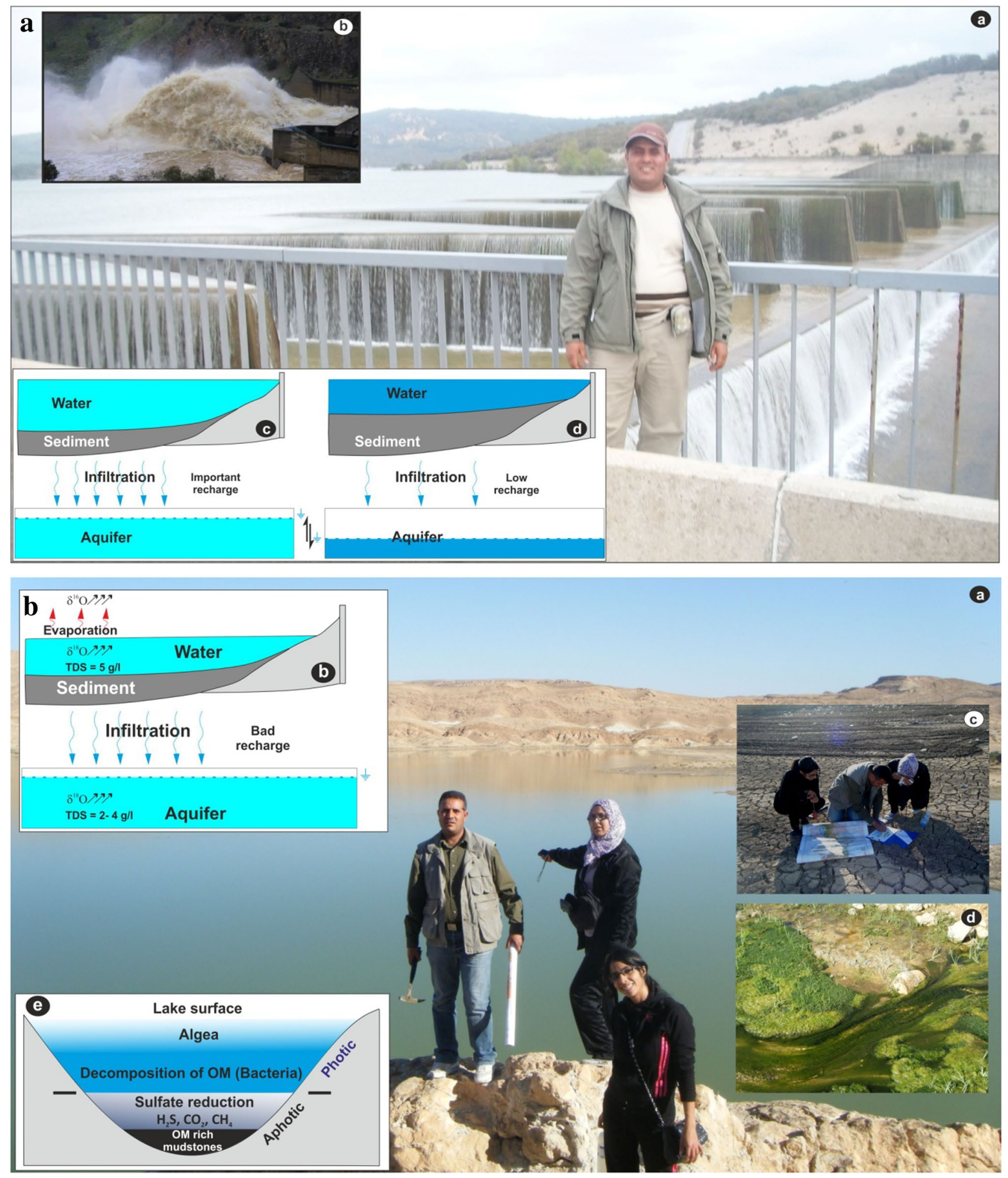

Fig. 3 a Model showing the climate effect on surface water of Tabarka Dam in the Tabarka region. b Model showing the effect of stagnation of surface water at the dams (El Khangua-Tamerza region, SW Tunisia) 
Fig. 4 Location map of Beni Harroun dam (NE Algeria)

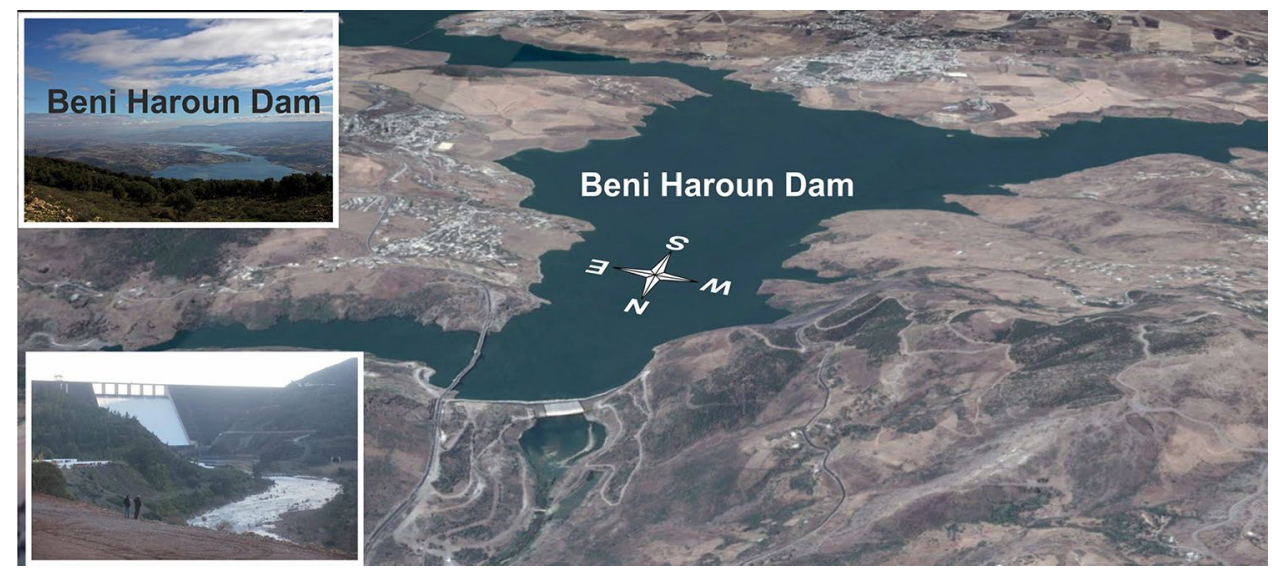

insects, etc. (Fig. 3b) (Hamed et al. 2014; Hamed 2015a, b).

The following simplified equation typifies the anoxygenic photosynthesis in purple or green sulphur bacteria (Warren 2016): $\mathrm{CO}_{2}+2 \mathrm{H}_{2} \mathrm{~S} \Rightarrow \mathrm{CH}_{2} \mathrm{O}+\mathrm{H}_{2} \mathrm{O}+2 \mathrm{~S}$.

In the Algerian territory, this phenomenon of stagnation of surface waters is very important in relation to Tunisian territory and therefore more catastrophic than Tunisia. Also, this trans-boundary Algero, Tunisian basin suffers from drought and the wastewater/waste sediment of phosphate Company (CPG/GCT-Gafsa-Tunisia and FERPHOSBir Elatter/Tebessa, Algeria). According to recent studies, droughts are endemic in both southern Europe and northern Africa (Pavel 2003; Khelifi et al. 2014, 2017; Mhamdi et al. 2014; Hamed 2017, 2018; El Gayar and Hamed 2017).

\section{Climate change effects on groundwater in North Africa}

Besides the direct effects of climate changes impacts on surface water availability and its suitability for utilization, the assessment of climate variability consequences on groundwater resources is still more complicated. Potential impacts of the drought trend on subterranean hydrogeologic systems are often evaluated in terms of quantity and quality deterioration depending on both natural and anthropogenic effects (IPCC, TAR 2001). Direct effects are related to the infiltration of rainfall water, changing in recharge conditions, and interaction with surface water while indirect effects are attributed to removing water from storage and increasing pumping, which may affect hydraulic conductivity, storage capacity, and compaction acceleration of the aquifer.

In the southern Mediterranean countries, the sensitive sectors are directly related to the exploitation of subterranean water reservoirs. Thus, the combined effects of arid conditions and climate change, leading to increased deterioration of groundwater resources, have been widely observed in many regions in the study area. Besides the increasing salinity issues clear enough in North Saharan basin, water resources in these regions are undergoing severe water quality deterioration. Pollution is among the most important threats for water resources in these regions where climate variability and the resulting human pressure will increase the spread of this pollution.

Both natural severe climate conditions and anthropological activities led to the hydrocarbon pollution of the Continental Intercalaire aquifer systems, the largest transboundary aquifer in North Africa (Algeria, Tunisia, and Libya). This contamination is irreversible and incurable. Its diffusion is of a hidden nature and difficult to manage (Hamed 2015a, b; Besser et al. 2017a). Water scarcity issues in these areas in the future are not only related to the availability of water resources but also to their suitability for different uses and especially for domestic and agricultural purposes.

In this regard, different approaches have been used in the evaluation of the groundwater quality for particular uses (Hamed et al. 2012, 2013, 2018; Besser et al. 2017b, 2018; Hadji 2017). Previous works proved that these waters are often unsuitable for both domestic uses and agricultural activities. The increasing exploitation of these saline and brackish waters leads to increasing risks for soil salinization and alkalinization. In the "Grand Erg" basin of North Africa (southern Tunisia and Algeria), the continuous exploitation of saline groundwater resources induces a severe soil degradation (Ben Hassine et al. 2016; Besser et al. 2017a; Hamed 2017). It may affect the main sector directly related to population incomes the agriculture by reducing yields and affecting crops quality.

Increasing groundwater salinity in coastal aquifers is mainly attributed to their overexploitation exceeding the regenerative capacity of the reservoir, which adds another dimension to the problem of water quality degradation. The decrease of the piezometric level below the seawater level induces continuous saline water intrusion from the sea to the coastal aquifer. These highly mineralized resources are often 
unsuitable for particular uses. In Tunisia, this phenomenon is widely expressed along the Mediterranean costs of the country mainly in the southeastern part (Gabès Gulf) as well as in the Cap-Bon areas (Tunis and Hamamet Gulfs) (Paniconi et al. 2001; Trabelsi et al. 2007; Agoubi et al. 2013; Kharroubi et al. 2014). The sea water intrusion in coastal aquifer (Fig. 5) can be explained by both natural causes, expressed by high sea level and climate change effects, and manmade perturbations attributed to continuous exploitation of the low renewable aquifers of arid and semi-arid regions. The marine intrusion has affected almost the entire coastal zone and essentially areas with strong agricultural or industrial/tourist activities (Annaba, Tunis, Hammamet, and Gabès Gulfs). Currently, following these unfavorable conjunctures, which are the seat of an imbalance on a socio-economic level, it is time to reflect on the project of management and mobilization east-west and north-south surface water (rainwater of dams), moving towards the transfer of seawater mainly to the Gafsa mining area (under study project, Hamed et al. 2017a, b, 2018), also towards the recycling of wastewater, etc. (Fig 5).

Overall, climate change carries threats related to the proliferation of diseases affecting wildlife and the intensification of plant pest activity (increase in generations). They threaten increase the risks to human health essentially. Climatic and environmental variations strongly influence the dynamics of epidemic plagues in Tunisia, such as meningitis, affecting between 20 and 30 people per year (HR-Gafsa and Gabes) (2013 is chosen as the reference year for our study in the two areas already mentioned). In 2014, the region of El Hamma (Gabes, Tunisia) also experienced the proliferation of another epidemic known as hepatitis A, caused mainly by the consumption of water contaminated bacteriologically under the effect of the contamination of the water table by discharges from septic tanks in the region following a cessation of drilling SONEDE for a few days followed by a rainy season that has led to an increase in piezometric levels, especially surface aquifers that are more vulnerable to pollution and which are similarly more exploited by the population of the region (Hamed 2015a, b). In this region of El Hamma, the thermal groundwater $\left(20{ }^{\circ} \mathrm{C}<\right.$ temp $\left.<90{ }^{\circ} \mathrm{C}\right)$ is overexploited in agricultural activities (biological agricultural in El Kbayet oases), industrial sector (GCT-Ghanouch), and also in therapeutic traditional baths (Fig. 6) (Hamed 2017).

Similarly, the continuous exploitation of low renewable continental aquifers, especially in southwestern Tunisia and Algeria, gives rise to leakage and interference issues between different water-bearing strata. This situation is aggravated by the presence of Chotts aquifer and the risks of saline-brackish water interference from the endorheic depression exposed to high evaporation potential. This situation is commonly observed in oases systems created around these salt lakes. The newly formed aquifers, created by the return of irrigation water, are exposed to a high level of evaporation within the gypsum loam sandy soils covering the oases result in the creation of gypsum crusts increasing soil infertility. The platitude of the area and the proximity of Chotts depressions reduce leakage of the accumulated salts (Hamed et al. 2008, 2010a, b; Ben Hassine et al. 2016; Besser et al. 2017b).

Figure 7 presents the coupled effects of human and climate stresses on groundwater quality in the SASS aquifer of North Africa "The North Western Sahara Aquifer System (NWSAS)", better known under the acronym SASS for its French name "Système Aquifère du Sahara Septentrional". It is a large aquifer shared by Algeria, Libya, and Tunisia. The NWSAS designates the superposition of two main deep aquifer layers: the Continental Intercalary (CI) and the Terminal Complex (CT). The SASS is the most heavily used aquifer in North Africa and supplies about $100 \%$ of the groundwater used in these regions for irrigation and domestic, industrial, and tourist sectors. This transboundary multi-aquifer has been recharged during the Late Pleistocene and the Early Holocene periods (Fig. 8). The Pleistocene and Holocene periods could be responsible for the periodic recharge of fossil groundwaters in North Africa. In the last $70 \mathrm{ka}$ before present (MIS 2 and MIS 3, Würm period), three major humid phases have been identified: the Early Würm Pluvial (MIS 3), lasting from 70 to $40 \mathrm{ka}$ before present, the Middle Würm Pluvial (MIS 3), from about 32 to about $22 \mathrm{ka}$ before present and the Late Würm Pluvial (MIS 2), lasting from about 18 to $11 \mathrm{ka}$ before present (Fontes et al. 1983; Ouda 2000; Yermani et al. 2002; Guendouz et al. 2003; Zuppi and Sacchi 2004; Hamed et al. 2008, 2010a, b, 2012a, 2013; Mokadem et al. 2016; Hamed 2017, 2018).

Among the consequences of this over-exploitation of groundwater are (Figs. 7, 8, 9, 10):

- artisianism extinction/decrease of pressure in deep wells;

- the springs were negatively affected (discharge declined and/or stopped);

- deterioration of the quality $(90 \mathrm{~g} / \mathrm{l}$ in deep well in gafsa basin "Ségui region") and the quantity;

- intercommunication between the water reservoirs and petroleum reservoirs due to the anarchic overexploitation of the groundwater;

- water and soil salinization (deterioration of structure and texture, perched aquifer neoformation, etc.): salinization effects in irrigated arid areas increase every day with the growing extent of irrigation system;

- saltwater intrusions (sea/Chott lands);

- degradation in the irrigated oases (vegetation degradation, sandification, alkalinization, desertification/desiccation in drylands, decrease of the agricultural productivity; 
Fig. 5 Location of surface and groundwater transfer, intrusion marine, and the recent project in Tunisia (Hamed et al. 2017a, b, 2018)

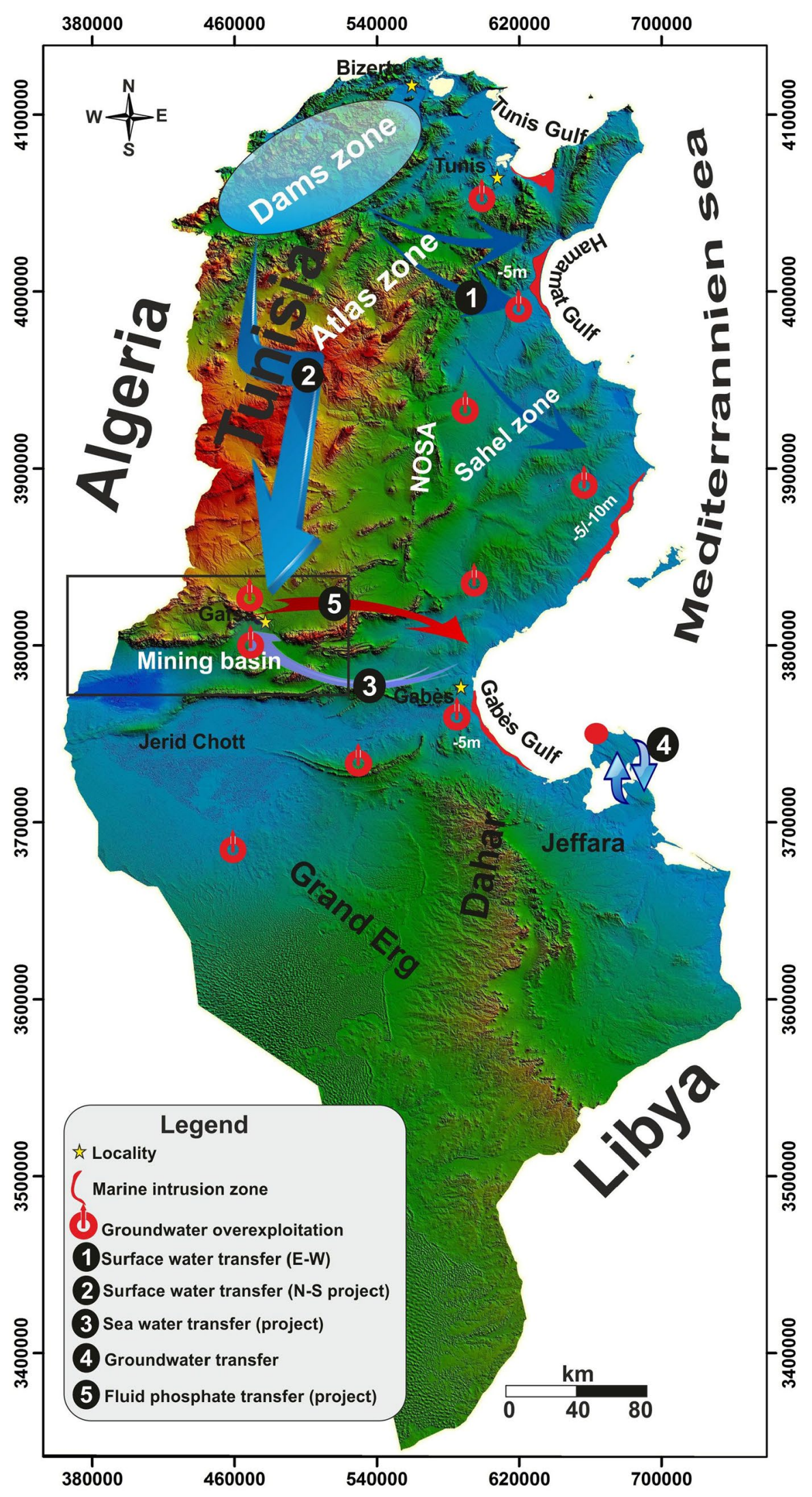




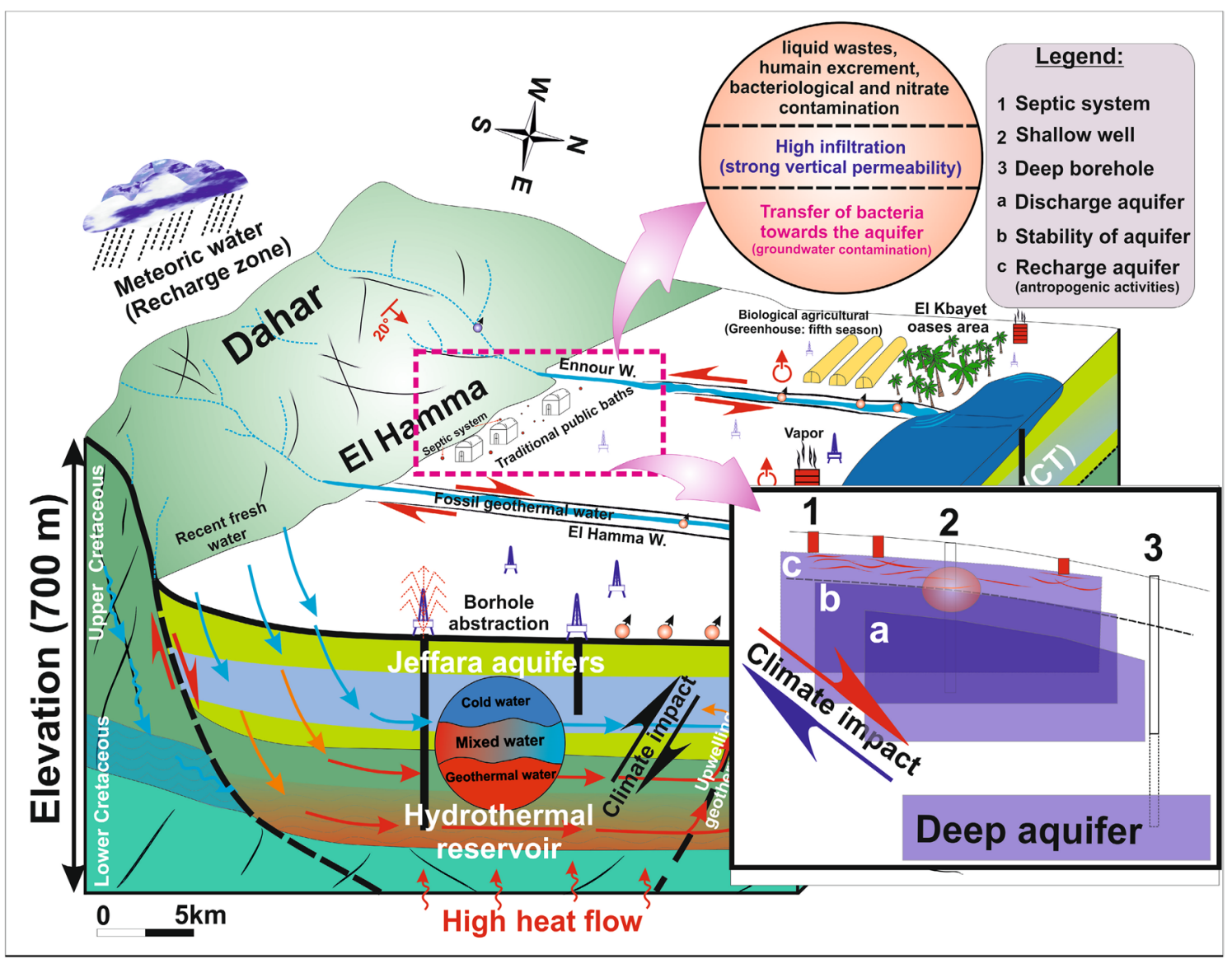

Fig. 6 Conceptual model of hydrodynamic of groundwater and the climate change in El Hamma region (SE Tunisia)

- upwelling of fossil and saline thermal water from C.I. aquifer;

- appearance of humid microclimates near the oases areas (evacuation of excess irrigation water to avoid plant asphyxia "especially the date palm: Phoenix dactylifera L." and other fruit and vegetables);

- increase of water scarcity and pumping costs;

- transboundary future global conflicts;

- socio-economic impacts (negative impacts on soils and land productivity, abandoning agricultural projects, migration etc.).

Similar to other regions of the world, groundwater in North Africa is a substantial economic resource that is threatened by over-exploitation and contamination from discharge pollutants (industrial sector), which could be exacerbated by climate effect.

Nowadays, over $60 \%$ of groundwater exploitation is in the private sector, and sometimes there is no control on its extraction. During the 2000 s, $80 \%$ of groundwater in southern of Tunisia suffered from abusive exploitation, expressed in the degradation of the quantity and quality. The piezometric level of the Complex Terminal (CT) is dropping at rates ranging from 0.6 to $5 \mathrm{~m} /$ year. However, concerning the Continental Intercalaire (CI), the decrease of the water level is about 0.2-1.2 m/year (Hamed 2015a, b) (Fig. 10). This decrease of the piezometric level is due to the effect of land use and groundwater uptake for the industrial (CPG, GCT, FerFos, petroleum activities) and agricultural sectors (oases area). This situation of piezometric level decrease of the SASS aquifer knew a rise during the period of realization of the great project of the artificial river in Libya $(-10 \mathrm{~m})$.

The situation of water resources deterioration and depletion is not limited to Tunisia, but is also the case in Morocco, Algeria, Libya, Egypt, Jordan, Saudi Arabia, and the Gulf States (Lloyd 1998; Margat 1992; Bank 1994; Foster 1992; Margat and Saad 1983; Margat 1992; Bouri et al. 2008; Hamed et al. 2010b; Mokadem et al. 2016; Hadji et al. 2017, Hadji 2018; El Gayar and Hamed 2017; Kachi et al. 2017; Hamed et al. 2017a, b; Besser et al. 2017a, b).

Actually, it is necessary for wastewater treatment and reuse to become an integral part of water services. Although wastewater is polluted, proper treatment can make it applicable in irrigation, industry sector and also 


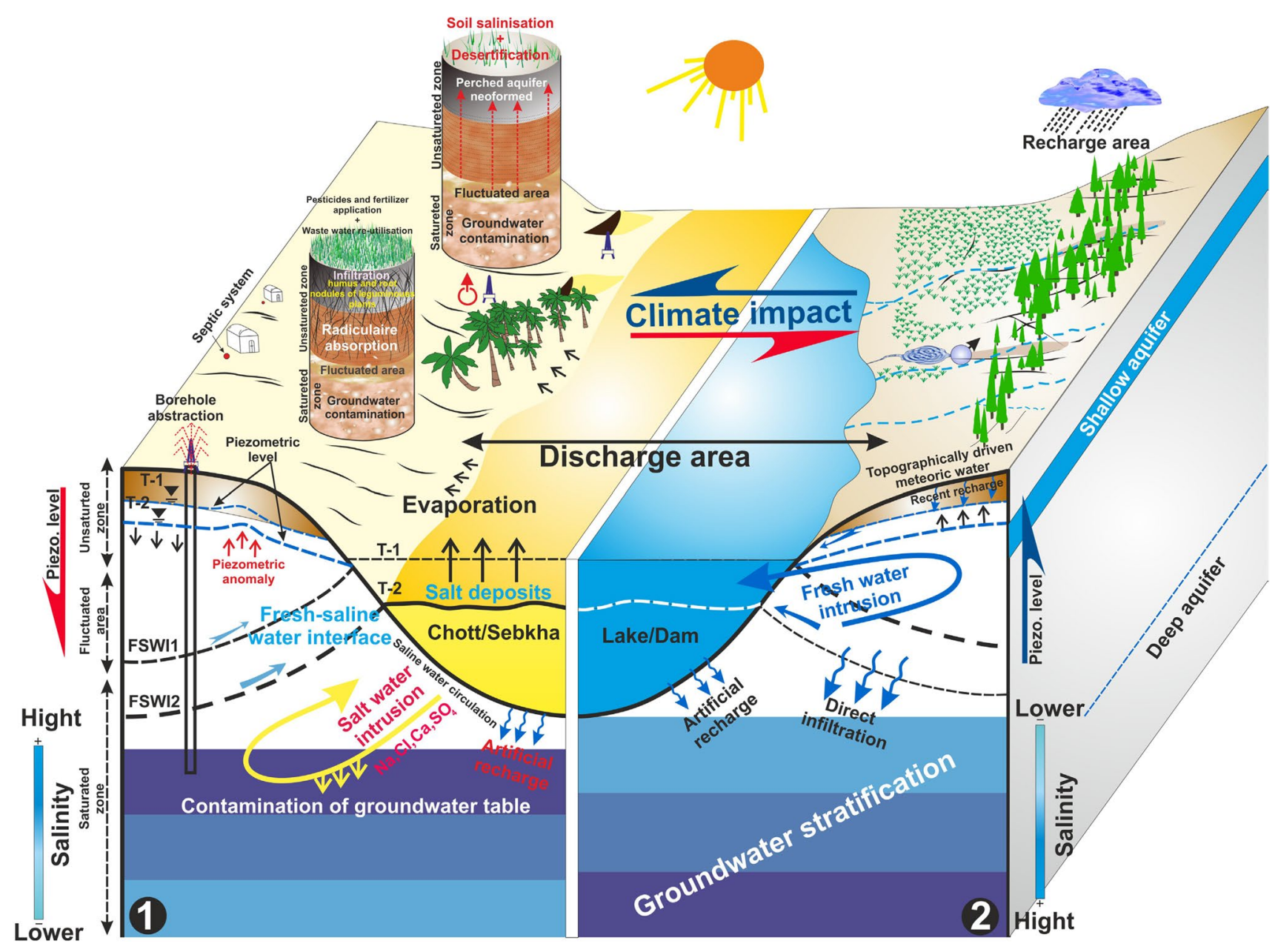

Fig. 7 Conceptual model showing the exchanges between the saline lake and the aquifer due to the overexploitation of groundwater and the climate impact (1)-arid climate; (2)-humid climate

in the artificial recharge of aquifers "natural purification". It is now necessary for wastewater treatment and reuse to become an integral part of water services. Although wastewater is polluted, proper treatment can make its application in irrigation quite safe. It also has advantages over fresh water: waste contains the nutrients necessary to support plant growth and we can valorize it for other uses.

In the case of northern Africa, the waters of the SASS are non-renewable "fossil", that is why the groundwater resources have to be exploited (mined) then the revenues from their use, even for domestic purposes, should be able to cover their substitution or they should be invested to enable future generations to substitute them from other resources or by using other technologies. For example, in the Gafsa mining basin, it is necessary to avoid the washing of phosphate by fresh water and also in the oil field. It is also necessary to bring sea water from the Gulf of Gabés (Hamed et al. 2017a, b, 2018) (Fig. 5).
Recent studies in the southern coast of the Mediterranean basin have shown that shallow aquifers suffer from the intrusion of seawater mainly due to the high water use (agricultural activities, industrial activities, domestic, and touristic demands). In these areas, saline groundwater comes from the sea and from deep saline aquifers, and subsequently intrudes the near-surface coastal groundwater system. The salinization of the subsoil is caused by human-driven processes of land subsidence that have been going on for nearly a millennium (Fig. 9). Among the most affected areas by the intrusion of sea water in North Africa are El jadida, Annaba, Korba, Sfax, and Gabès (Trabelsi et al. 2007; Hamed 2015a, b; Kharroubi et al. 2012; Agoubi et al. 2013; Redhaounia et al. 2015; Telahigue et al. 2018).

Once conventional water resources become scarcer, governments would turn to restrictive measures on water demands or to more effective use of existing resources and also to non-conventional sources for countries where 


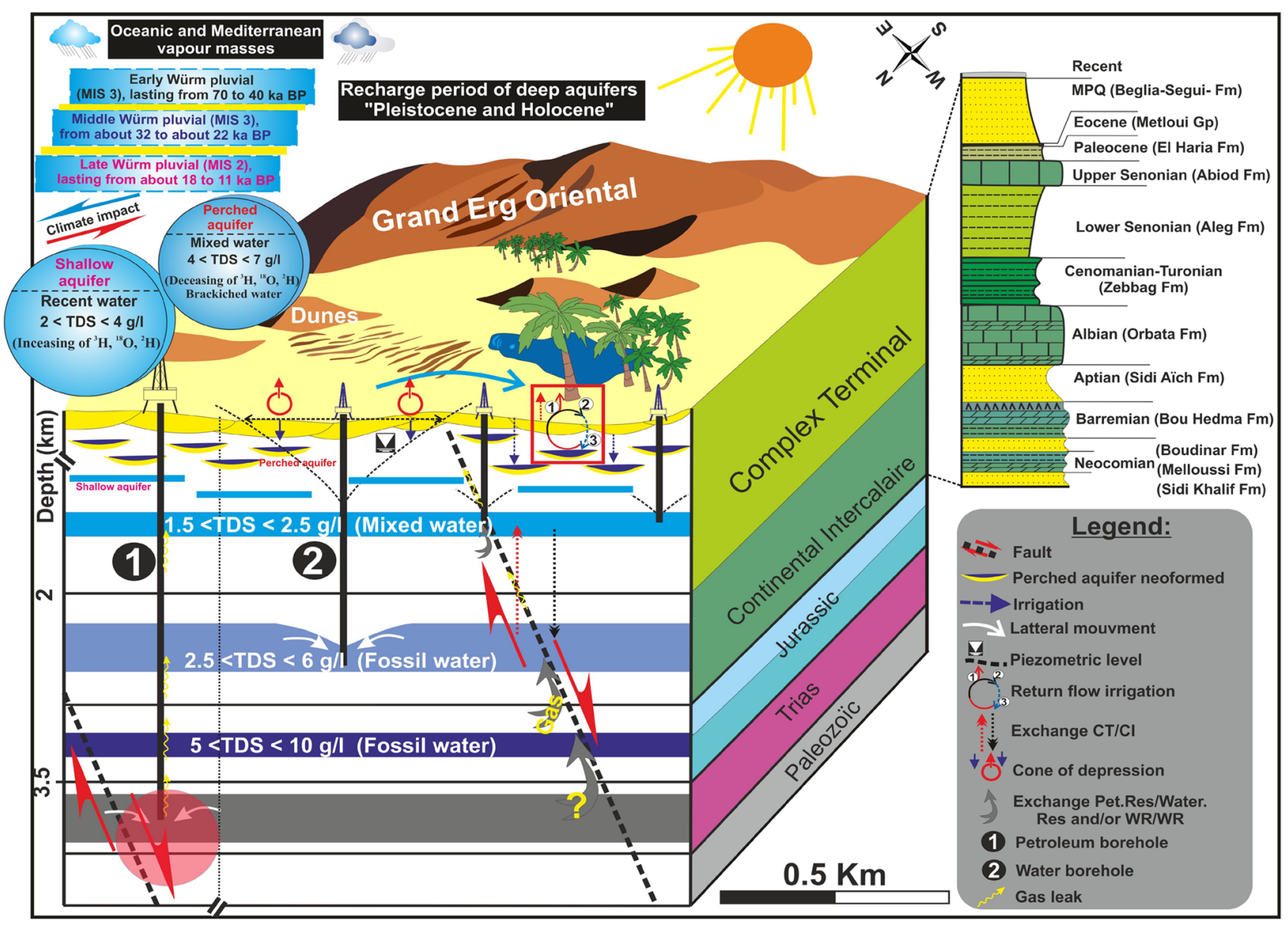

Fig. 8 Conceptual model showing the groundwater hydrodynamic and the intercommunication between CT and CI aquifers (Hamed 2015a, b)

water consumption exceeds the limits/low renewable water resources. In southern Mediterranean countries, the treated wastewater constitutes firstly the main alternative for increasing supplies despite the fact that it is still occasionally applied for watering municipal gardens and agricultural fields or for certain industrial processes. Thus, increasing attention for desalinated water is often the last resort for countries to overcome water shortages, which in the case of sea water is principally unlimited resources provide an alternative to inter-basin transfers of a considerable potential to constitute to the alleviation of global water scarcity. Seriously, constrained natural water supplies in the region are forcing North Africa to follow the Middle East and develop seawater and brackish desalination programs. In southern Mediterranean countries, Algeria is a good example to follow with a number of small-scale desalination plants to supply towns along the Mediterranean costs while Tunisia after its successful experience in brackish water desalination. The first large seawater reserve osmosis desalination plant at Djerba island (SE Tunisia) (Hamed 2017). However, the main challenges for sea water desalination are that it requires heavy capital investment and high operation and maintenance costs. Furthermore, the impacts of these alternatives on marine environment are not ignorable.

\section{Conclusions and recommendations}

Climate change is associated with changes in both surface and groundwater supply for domestic, agricultural, industrial, and tourism uses, including irrigation, navigation, and fishing, etc. (IPCC, TAR 2001). The impacts also depend on the baseline condition of the water supply system and the ability of water resource managers to respond to population growth and changes in demands, technology, and economic, social, and legal conditions (IPCC, TAR 2001; Hamed 2017). The meteorological disasters such as floods, overexploitation, marine intrusion, and droughts have major effects on food supplies, health, economic, and environmental losses, and social upheaval (Hargreaves and Samani 1985; Harrison and Whittington 2002; Pavel 2003; Goulden et al. 2009; Barrios et al. 2010; Hamed 2017; El Gayar and 


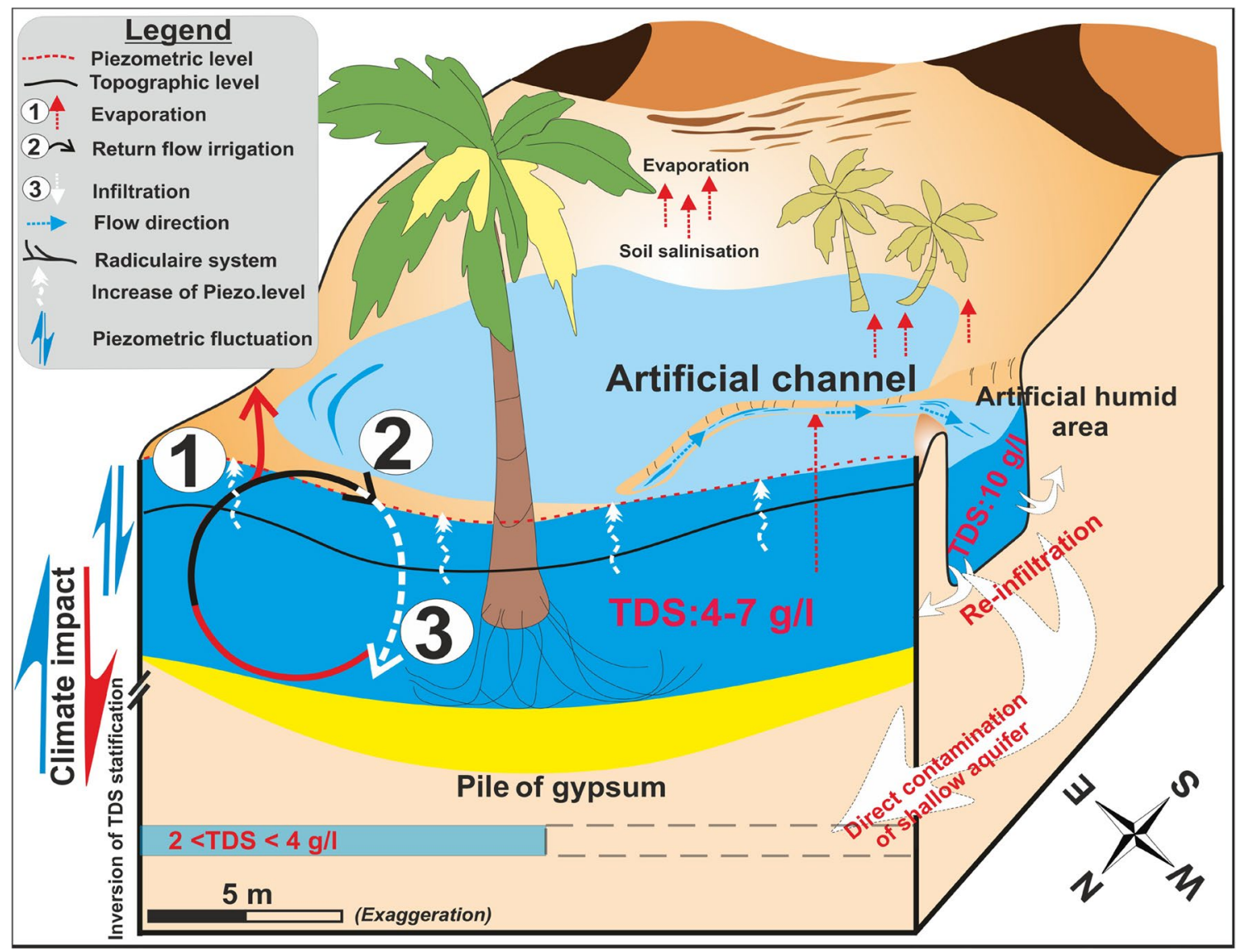

Fig. 9 Conceptual model showing the soil salinization in southern Tunisia

Hamed 2017). Given the complexity of climate change impacts, both there are clearly crude indicators of actual impacts involved in stress and shortage (Blanc and Strobl 2012; Conway et al. 2009; Deichman et al. 2010).

Climatic changes can be a serious threat to reduce poverty and achieve sustainable development. The North African regions are likely to suffer the most devastating effects of this change because of their geographical location, low institutional capacity to adapt to rapid environmental changes, low incomes of their population, their greater reliance on climate-sensitive sectors, the bad management of water resources, and especially inadequate government mechanisms.

In order to take such problems into account, the following recommendations will be very helpful:

- Rethinking the management of the water sector has become urgent and radical changes towards a balanced resources/demands equation seems to be inevitable for a continuous yield of water resources to guarantee future generations equity in these resources.

- It is necessary to move towards the use of wastewater and desalinization of seawater, especially for the industrial sector and the good management of surface water must be sought.

- Establish continental mechanisms to combat climate effect, drought, and desertification.

- Protect the vulnerable areas of the study region;

- Strengthen building-mechanisms capacity for surface and groundwater.

- Adopt a common platform and position on North Africaclimate effect-water resources related issues at continental/oceanic and international levels.

- Move towards smart agriculture, renewable energies, construction of green dams, transfer of dams (E-W and $\mathrm{N}-\mathrm{S}$ ) to avoid the loss of rainwater to the sea, forestation by plants with high tolerances of salinity and which adapt to the dryness of the arid environment.

- Pumping of waterlogged areas. Salt can be flushed away from soils and/or desalinated "artificial recharge".

- Now more than ever, we need to be weather-ready, climate-smart, and water-wise. 

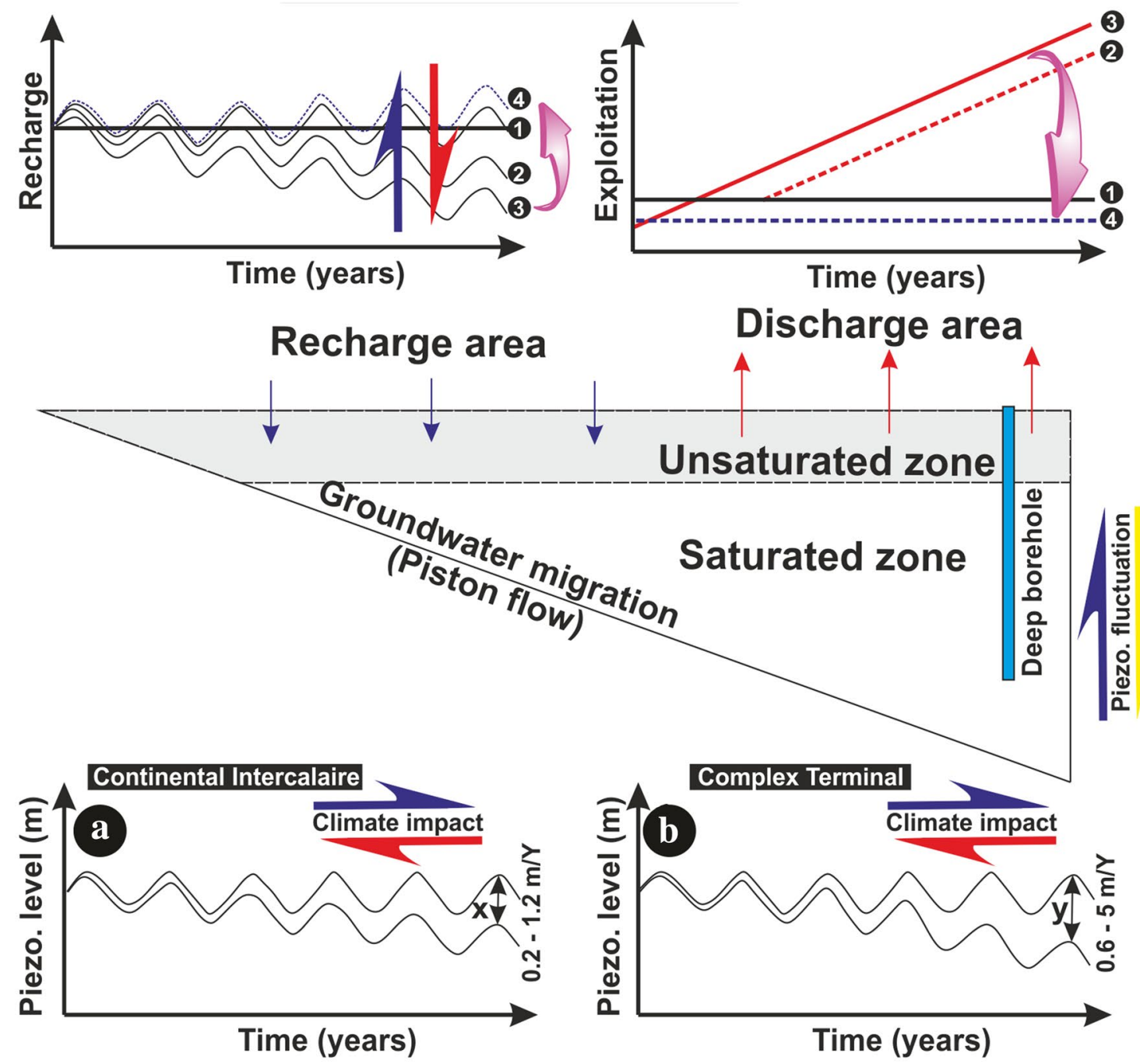

Discharge area
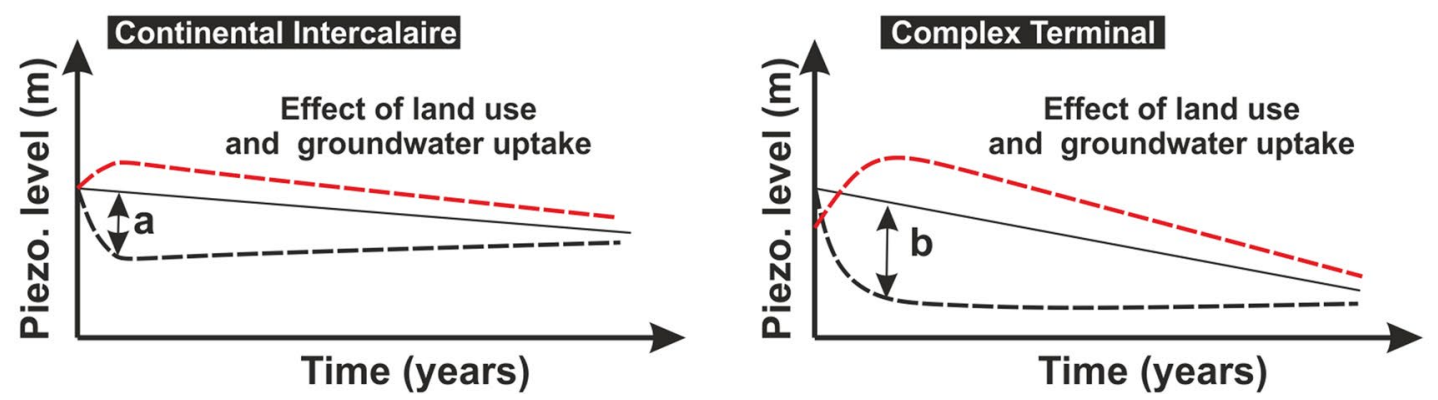

Fig. 10 Conceptual model showing the impact of climate change on (CI and CT groundwater) in SW Tunisia (synthesis of several studies Khelifi et al. 2014; Hamed et al. 2014; Mokadem et al. 2016)

Acknowledgements The authors greatly appreciate the comments from anonymous reviewers for the improvement of this paper. The authors would like also to thank the numerous people who helped in the preparation of this paper. The following list is not exhaustive, but perhaps more than most, the people listed will know of my interest in climate change. Many thanks are due to the international scientific committee of the first International Symposium (WREIANA 2017) of "Water Resources and Environmental Impact Assessment in North Africa"-March 24-26, 2017 Gafsa-Tunisia for the selection of this paper to be submitted for consideration in the volume consisting of selected papers based on oral presentations from the scientific meeting. 


\section{Compliance with ethical standards}

Conflict of interest We declare that there are no conflicts of interest associated with this manuscript.

Open Access This article is distributed under the terms of the Creative Commons Attribution 4.0 International License (http://creativecommons.org/licenses/by/4.0/), which permits unrestricted use, distribution, and reproduction in any medium, provided you give appropriate credit to the original author(s) and the source, provide a link to the Creative Commons license, and indicate if changes were made.

\section{References}

Agoubi B, Kharroubi A, Abida H (2013) Hydrochemistry of groundwater and its assessment for irrigation purpose in coastal Jeffara aquifer, southeastern Tunisia. Arab J Geosci 6(4):1163-1172

Ayadi Y, Mokadem N, Besser H, Khelifi F, Harabi S, Hamad A, Boyce A, Laouar R, Hamed Y (2017a) Hydrochemistry and stable isotopes $\left(\delta^{18} \mathrm{O}\right.$ and $\left.\delta^{2} \mathrm{H}\right)$ tools applied to the study of karst aquifers in southern Mediterranean basin (Teboursouk area, NW Tunisia). J Afr Earth Sci 137:208-217

Ayadi Y, Redhaounia B, Mokadem N, Harrabi S, Hamed Y (2017b) Study of the karst system of the Teboursouk region (NW Tunisia). In: The 1st international symposium (WREIANA 2017) March 24-26, 2017 Gafsa, Tunisia

WB: World Bank (1994) A strategy for managing water in the ME and NA, HD1698. M53 B47, Washington

Barrios S, Bertinelli L, Strobl E (2010) Trends in rainfall and economic growth in Africa: a neglected cause of the African growth tragedy. Rev Econ Stat 92(2):350-366

Bates B, Kundzewicz Z, Wu S (2008) Climate change and water. Intergovernmental Panel on Climate Change Secretariat

Ben Hassine J, Gutiérrez-Rodríguez J, Escoriza D, Martínez-Solano I (2016) Inferring the roles of vicariance, climate and topography in population differentiation in Salamandra algira (Caudata, Salamandridae). J Zool Syst Evolut Res 54(2):116-126

Besser H, Mokadem N, Redhouania B, Rhimi N, Khlifi F, Ayadi Y, Omar Z, Bouajila A, Hamed Y (2017a) GIS-based evaluation of groundwater quality and estimation of soil salinization and land degradation risks in an arid Mediterranean site (SW Tunisia). Arab J Geosci 10:350. https://doi.org/10.1007/s1251 7-017-3148-0

Besser H, Mokadem N, Redhouania B, Ayadi Y, Khelifi F, Harabi S, Hamed Y (2017a) Groundwater mixing and geochemical assessment of low enthalpy resources in the geothermal field of southern Tunisia. In: The 1st international symposium (WREIANA 2017), Gafsa

Besser H, Mokadem N, Redhaounia B, Hadji R, Hamad A, Hamed Y (2018) Groundwater mixing and geochemical assessment of low-enthalpy resources in the geothermal field of southwestern Tunisia. Euro Mediterr J Environ Integr 3(1):16

Blanc E, Strobl E (2012) The impact of climate change of crop yields in Sub-Saharan Africa. Am J Clim Change 1:1-13

Bouri B, Makni J, Ben Dhia H (2008) A synthetic approach integrating surface and subsurface data for prospecting deep aquifers: the southeast Tunisia. Environ Geol. https://doi.org/10.1007/s0025 4-007-0928-y

Conway D, Persechino A, Ardoin-Bardin S, Hamandawana H, Dieulin C, Mahe G (2009) Rainfall and water resources variability in Sub-Saharan Africa during the 20th century. J Hydrometeorol 10:41-59
Deichman U, Meisner C, Murray S, Wheeler D (2010) The economics of renewable energy expansion in rural Sub-Saharan Africa. Energy Policy 39:215-227

El Gayar A, Hamed Y (2017) Climate change and water resources management in Arab countries. Springer, AG-Euro-Mediterranean and Surrounding Regions, Advances in Science, Technology and Innovation, https://doi.org/10.1007/978-3-319-70548-4-31

Fontes JC, Coque R, Dever L, Filly A, Mamou A (1983) Paleohydrologie isotopique de l'wadi el Akarit (sud tunisien) au Pleistocene et à l'Holocene. Pal 43:41-61

Foster SSD (1992) Unsustainable development and irrational development of groundwater resources in developing nations: selected papers on aquifer overexploitation. Int Assoc Hydrogeol (IAH) Hydrogeol Sel Pap 3:321-336

Goulden M, Conway D, Persechino A (2009) Adaptation to climate change in international basins in Africa: a review. Hydrol Sci 54(5):805-828

Guendouz A, Moulla AS, Edmunds WM, Zouari K, Shand P, Mamou A (2003) Hydrogeochemical and isotopic evolution of water in the complex terminal aquifer in the Algerian Sahara. J Hydrol 11:483-495

Hadji R (2017) Induction of climate change on mass wasting frequency in Northeast of Algeria. The 1st International Symposium (WREIANA 2017), Gafsa

Hadji R, et al. (2018) Using GIS and RS for slope movement susceptibility mapping: comparing AHP, LI and LR methods for the Oued Mellah basin, NE Algeria. In: Book: recent advances in environmental science from the Euro-Mediterranean and surrounding regions. https://doi.org/10.1007/978-3-319-70548-4-536

Hadji R, Rais K, Gadri L, Chouabi A, Hamed Y (2017) Slope failure characteristics and slope movement susceptibility assessment using GIS in a medium scale: a case study from Ouled Driss and Machroha municipalities, northeast Algeria. Arab J Sci Eng 42(1):281-300

Hamad A, Baali F, Hadji R, Zerrouki H, Besser H, Mokadem N, Legrioui R, Hamed Y (2018) Hydrogeochemical characterization of water mineralization in Tebessa-Kasserine karst system (TunisoAlgerian Transboundary basin) Euro-Mediterr. J Environ Integr. https://doi.org/10.1007/s41207-017-0045-6

Hamed Y (2015a) Fonctionnement et dynamisme des ressources hydriques des aquifères en milieu aride à semi-aride: approche hydrogéologique, hydrochimique et isotopique. HDR, Sciences Faculty of Sfax. p 160

Hamed Y (2015b) L'Or Bleu et les Changements Climatiques en Tunisie. Editions universitaires europeennes, p 456 (ISBN-13:978-3639-50823-9, ISBN-10: 3639508238)

Hamed Y (2017) Projet pilote: nouvelle Tunisie «Apport d'eau de mer du Golfe de Gabès à Gafsa: Aspects socio-économiques et Exploitation». In: The 1st international symposium (WREIANA 2017), Gafsa

Hamed Y (2018) Climate change and water resources in North Africa. Study day on water resources. University of Sétif, Sétif. http:// iast.univ-setif.dz/2-non-categorise/208-conference-younes-hamed -seminaire-iast. Accessed 9 Apr 2018

Hamed Y, Dassi L, Ahmadi R, Ben Dhia H (2008) Geochemical and isotopic study of the multilayer aquifer system in the MoularesRedayef basin, southern Tunisia. Hydrol Sci J. 53(5):1241-1252

Hamed Y, Dassi L, Tarki M, Ahmadi R, Mehdi K, Ben Dhia H (2010a) Groundwater origins and mixing pattern in the multilayer aquifer system of the Gafsa-south mining district: a chemical and isotopic approach. Environ Earth Sci 63:1355-1368

Hamed Y, Zairi M, Ali W, Ben Dhia H (2010b) Estimation of residence times and recharge area of groundwater in the moulares mining basin by using carbon and oxygen isotopes (south western Tunisia). J Environ Prot 1:466-474 
Hamed Y, Ahmadi R, Hadji R, Mokadem N, Ben Dhia H, Wassim A (2012) Groundwater evolution of the continental intercalaire aquifer of southern Tunisia and a part of southern Algeria: use of geochemical and isotopic indicators. Desalination Water Treat J. https://doi.org/10.1080/19443994.2013.806221

Hamed Y, Al-Gamal SA, Ali W, Nahid A, Dhia HB (2013) Palaeoenvironments of the continental intercalaire fossil from the Late Cretaceous (Barremian-Albian) in North Africa: a case study of southern Tunisia. Arab J Geosci. https://doi.org/10.1007/s1251 7-012-0804-2

Hamed Y, Ahmadi R, Demdoum A, Bouri S, Gargouri I, Dhia HB, Al-Gamal SA, Laouar R, Choura A (2014) Use of geochemical, isotopic, and age tracer data to develop modelsof groundwater flow: a case study of Gafsa mining basin-Southern Tunisia. J Afr Earth Sci 100:418-436

Hamed Y, Hadji R, Redhaounia B, Bâali F, El Gayar A (2017) Climate impact on surface and groundwater in North Africa-a global synthesis of findings and recommendations. In: The 1st international symposium (WREIANA 2017) Gafsa

Hamed Y, Redhaounia B, Ben Sâad A, Hadji R, Zahri F (2017b) Groundwater inrush caused by the fault reactivation and the climate impact in the mining Gafsa basin (southwestern Tunisia). J Tethys 5(2):154-164

Hamed Y, Bouguerra W, Limam E (2018) Projet pilote « transfert d'eau de mer du Golfe de Gabès à Gafsa: Aspects socio-économiques et Exploitation». Tunis 2 Mars 2018 ANPR-Tunisie

Hammouri M, Fohtung E, Vasiliev I (2016) Ab initio study of magnetoelectric coupling in $\mathrm{La} 0.66 \mathrm{Sr} 0.33 \mathrm{MnO} 3 / \mathrm{PbZr} 0.2 \mathrm{Ti0} 0 \mathrm{O} 3 \mathrm{mul}-$ tiferroic heterostructures. J Phys Condens Matter 28(39):396004

Hargreaves GH, Samani ZA (1985) Reference crop evapotranspiration from temperature. Appl Eng Agric 1:96-99

Harrison GP, Whittington HBW (2002) Susceptibility of the Batoka Gorge hydroelectric scheme to climate change. J Hydrol 264:230-241

Kachi N, Kachi S, Bousnoubra H (2017) Impact de l'intensification agricole sur la qualité du sol et des resources hydriques dans le perimetre irrigué de Guelma. In: The 1st international symposium (WREIANA 2017), Gafsa

Kharroubi A, Telahigue F, Agoubi B, Azri C, Bouri S (2012) Hydrochemical and statistical studies of the groundwater salinization in Mediterranean arid zones: case of the Jerba coastal aquifer in southeast Tunisia. Environ Earth Sci 67(7):2089-2100

Kharroubi A, Farhat S, Agoubi B, Lakhbir Z (2014) Assessment of water qualities and evidence of seawater intrusion in a deep confined aquifer: case of the coastal Djeffara aquifer (Southern Tunisia). J Water Supply Res Technol-Aqua 63(1):76-84

Khelifi F, Naziha M, Mhamdi S, Redhaounia R, Ayadi Y, Hamed Y (2014) Analysis and assess of the climate change and its impact on water resources based on the GIS technology in the Djerid basinSouthwestern Tunisia. ${ }^{\mathrm{er}}$ colloque international (Hydrogéologie et Géothermie) le 11 et 12 Novembre. Guelma

Khelifi F, Redhaounia B, BenAssi R, Hamed Y (2017) Impact of the phosphate industry in the Gafsa mining basin: environmental threat and health risks. In: The 1st International Symposium (WREIANA 2017), Gafsa

Lloyd JW (1998) A changing approach to arid zone groundwater resources in developing countries? In: van Brahana J et al (eds) Gambling with groundwater. International Association of Hydrogeologists, Las Vegas, pp 7-12

Margat G (1992) The over-exploitation of aquifers. Selected papers on aquifer over-exploitation. Int Assoc Hydrogeol Heiss Hann 3:29-40
Margat G, Saad KF (1983) Concepts for the utilization of non-renewable groundwater resources in regional development. Nat Res Forum 7(4):377-383

Melki A, Abdollahi K, Fatahi R, Abida H (2017) Groundwater recharge estimation under semi arid climate: case of northern Gafsa watershed, Tunisia. J Afr Earth Sci 132:37-46

Mhamdi S, Khlifi F, Mokadem M, Hamed Y (2014) The climate change on groundwater in the Gabès basin (Eastern of Tunisia)-North Africa. $1^{\text {er }}$ colloque international (Hydrogéologie et Géothermie) le 11 et 12 Novembre 2014. Guelma

Mokadem N, Demdoum A, Hamed Y, Bouri S, Hadji R, Boyce A, Laouar R, Sâad A (2016) Hydrogeochemical and stable isotope data of groundwater of a multi-aquifer system: northern Gafsa basin-central Tunisia. J Afr Earth Sci 114:174-191

Ouda B (2000) Paléohydrologie isotopique du bassin de Meknassi (Tunisie centrale) pendant le quaternaire recent Paleohydrology

Paniconi C, Khlaifi I, Lecca G, Giacomelli A, Tarhouni J (2001) Modeling and analysis of seawater intrusion in the coastal aquifer of eastern Cap-Bon. Tunisia. Transp Porous media 43(1):3-28

Pavel K (2003) Climate changes the water rules: how water managers can cope with today's climate variability and tomorrow's climate change. Published in The Netherlands by the Dialogue on Water and Climate; Nature. p 106

Pittock AB (2007) Climate change: turning up the heat. EARTHSCAN, Australia, p 316

Radhouane L (2013) Climate change impacts on North African countries and on some Tunisian economic sectors. J Agri Environ Intern Dev (JAEID) 107(1):101-113

Redhaounia B, Aktarakçi H, Batobo OI, Gabtni H, Khomsi S, Bédir M (2015) Hydrogeophysical interpretation of fractured and karstified limestones reservoirs: a case study from Amdoun region (NW Tunisia) using electrical resistivity tomography, digital elevation model (DEM) and hydrogeochemical approaches. J Afr Earth Sci. https://doi.org/10.1016/j.jafrearsci.2015.09.020

Telahigue F, Agoubi B, Souid F, Kharroubi A (2018) Groundwater chemistry and radon-222 distribution in Jerba Island, Tunisia. J Environ Radioact 182:74-84

Trabelsi R, Zairi M, Ben Dhia H (2007) Groundwater salinization of the Sfax superficial aquifer. Tunis Hydrogeol J 15:1341-1355. https://doi.org/10.1007/s10040-007-0182-0

UNEP (2006) Africa's lakes: atlas of our changing environment, Nairobi

UNEP (2010) "Africa water Atlas". Division of early warning and assessment (DEWA). United nations environment programmed (UNEP), Nariobi

UNEP (2011) Vital climate graphics Africa. Retrieved from http:// www.grida.no/publications/vg/africa/page/3116.aspx

Warren JK (2016) Halotolerant life in feast or famine: organic sources of hydrocarbons and fixers of metals. Evaporites: a geological compendium. Springer, Cham

Yermani M, Zouari K, Michelot JL, Mamou A, Moumni L (2002) Approche géochimique du fonctionnement de la nappe profonde de Gafsa Nord (Tunisie centrale)/Geochemical approach to the functioning of the Gafsa North deep aquifer (central Tunisia). Hydrol Sci J 48(1):95-108

Zuppi GM, Sacchi E (2004) Hydrogeology as a climate recorder: Sahara-Sahel (North Africa) and the Po Plain (northern Italy). Glob Planet Change 40:79-91 